\title{
Utilization of Google My Business as a Tourism Promotion Media Using Local Search Engine Optimization
}

\author{
Ayi Purbasari ${ }^{1}$, Ghesti Prabawati Maryono ${ }^{2}$, Ferry Mulyanto ${ }^{3}$,Wanda Gusdya ${ }^{4}$ \\ Jurusan Teknik Informatika Universitas Pasundan \\ e-mail: pbasari@unpas.ac.id ,Ghesti.153040058@mail.unpas.ac.id , ferry@unpas.ac.id , \\ Wanda.gusdya@unpas.ac.id
}

To cite this document:

Purbasari, A., Maryono, G. P., Mulyanto, . F. M., \& Gusdya, W. (2020). Utilization of Google My Business as a Tourism Promotion Media Using Local Search Engine Optimization. IAIC Transactions on Sustainable Digital Innovation (ITSDI), 2(2), 169-178.

DOI : https://doi.org/10.34306/itsdi.v2i2.417

\begin{abstract}
The tourism industry is an industry that continues to grow in the world, including in Indonesia. Likewise, Kebumen Regency has various tourism potentials ranging from water tourism, mountain tourism, culinary tours, cave tours, cultural tourism and others. One of them is Curug Sindaro, which is located in the north of Kebumen Regency which is precisely located in Wadasmalang Village, Karangsambung District, Kebumen Regency, Central Java. However, in the process of developing and managing it, the tour, which was inaugurated on March 3, 2019, is increasingly experiencing a decline in visitors. Which is where, the main problem is that the promotion is still not optimal.

In the existing tourism development process, of course, requires the media used to carry out promotions with a good marketing strategy. In order to be easily affordable, the right marketing strategy to use is an online marketing strategy. By analyzing promotional needs and analyzing keywords, it can maximize promotion.

The purpose of this research is to implement Local SEO using Google My Business as a promotional medium for Wisata Curug Sindaro which is an online marketing strategy. If the Sindaro waterfall tour is promoted through Google my business, tourists around the Sindaro waterfall will find it easy to find Sindaro waterfall tourism through google and it is hoped that visitors will increase. Because, in this Google My Business has sufficient features for promotion. With the initial stage of registering a Google My Business account, then claiming an existing business. Because previously the Sindaro Curug Tour was already on Google Pages. With several stages of verification and changing the cellphone number that stated the Google My Business account for Sindaro Curug Tourism has been successfully created. However, due to the verification method there are obstacles that have been successfully created is the web page for the Sindaro Waterfall Tour.
\end{abstract}

Keywords: Travel, Promotion, Local SEO, Google My Business

Utilization of Google My Business... 


\section{Introduction}

Tourism is a growing industry in the world [10]. Including in Indonesia. For a long time, tourism in developed countries is part of the necessities of life [10]. Likewise, Kebumen Regency has various tourism potentials ranging from water tourism, mountain tourism, culinary tourism, cave tourism, cultural tourism and others. Many new tours are being developed by the Kebumen Regency government, one of which is Curug Sindaro which is located in the north of Kebumen Regency which is precisely located in Wadasmalang Village, Karangsambung District, Kebumen Regency, Central Java.

In the existing tourism development process, of course, requires the media used for promotion. Media that can be used include using print media ormedia

electronic. Along with technological developments, it greatly affects how business people promote their products or the tourist attractions that are being managed. The media that is often used as a means of promotion are social media such as Instagram, Facebook, Twitter, Pinterest, and others. One of them has done a promotion through Instagram social media, namely the Floating Market in Lembang, West Bandung Regency, West Java [5]. The decrease in visits occurred due to the absence of a marketing strategy that was applied in promotion, and also the manager's ignorance of how to carry out marketing strategies.

Currently, the promotion media carried out in the management of Curug Sindaro uses social media such as Facebook, Instagram and WhatsApp. However, the management is still not optimal, because the promotion media still lacks role. Given, the Wadasmalang Village government wants to introduce the Sindaro Waterfall Tour itself to the wider community, especially for the people of Kebumen Regency.

Based on these problems, there needs to be a marketing strategy for promotion. In order to be easily affordable, the marketing strategy that is carried out is an online marketing strategy. The implementation of Local SEO uses Google My Business which does have features for adequate promotion. If the Sindaro Curug Tour is promoted through Google my business, tourists around the Sindaro Waterfall will easily find the Sindaro Waterfall Tour through Google and visitors are also expected to increase.

\section{Dasar Theory}

\section{A. Promotions}

Promotions Is a key element in the marketing campaign as a collection of tools that most of the intensive short term, which are designed to stimulate the purchase of specific products or services faster and larger to consumers [12]. Promotion can also be interpreted as part of the marketing process which includes one aspect of the marketing mix (marketing mix). The marketing mix is basically a coordinating interaction of four components, which are often referred to as 4Ps, namely Product, Price , Place (Location of Distribution), and Promotion (Promotion) [12].

Based on the above understanding, it can be concluded that promotion is a company activity to communicate that provides a convincing explanation and stimulates the purchase of a product or service by the target market [12].

\section{B. Tourism}

Based on Law Number 9 of 1990 concerning Tourism, it can be explained that the definition of a tourist area is an area that has a certain area which is developed and provided for tourism activities. When associated with water tourism, this meaning has the meaning of an area provided for tourism activities by relying on the object or attraction of the water area. Then based on the Law of the Republic of Indonesia Number 10 of 2009 concerning Tourism, 
it explains that a tourist attraction is anything that has uniqueness, beauty, and value in the form of a diversity of natural, cultural and man-made wealth that is the target of tourist visits [12] .

\section{Area and District Development Plan. Kebumen}

In general, Kebumen Regency is an area that continues to develop and is very dynamic, with the dynamics of development that occur in the political, economic and socio-cultural fields, which encourage development in every sector of the life of its people. Based on the RTRW (Regional Spatial Plan) document of Kebumen Regency 2011-2031, the development of Kebumen Regency has been planned to become several regional spatial structures. The spatial structure plan includes a central activity system, district infrastructure network. The central system of activities includes urban and rural systems [2].

In order to achieve the development goals and targets for 2017, the theme for the development of Kebumen Regency in 2017 is "Accelerating Agricultural-Based Economic Growth for Community Welfare". This theme implies that the potential and products of Kebumen must have marketability in the general market both at national and international levels, and are expected to be able to improve the community's economy which in turn will improve the welfare of the Kebumen community as a whole [2].

Plans for 2017 regional priority programs and activities are prepared based on the stages and mechanisms contained in Permendagri Number 54 of 2010 concerning Implementation of Government Regulation Number 8 of 2008 concerning Stages, Procedures for Preparation, Control and Evaluation of the Implementation of Regional Development Plans. The development target of Kebumen Regency in 2017 is aimed at accelerating agricultural-based economic growth for the welfare of the community. In planning in the tourism sector, among others are:

a. Tourism Marketing Development Program b. Tourism Destination Development Program c. Partnership Development Program [2]

\section{Digital Marketing}

The Internet, web and digital media have transformed marketing and business since the first website (http://info.cern.ch) was broadcast in 1991. With over 3 billion people worldwide regularly use the web to find products, entertainment and friends. Consumer behavior and the way companies market to business consumers have changed drastically [3].

In simple terms, Digital Marketing can be defined as "Achieving marketing goals through the application of technology and digital media." This concise definition helps remind that the returns generated by technology determine investment in Internet Marketing, not technology adoption. Digital marketing has several marketing techniques including search engine marketing, social media marketing, online advertising, email marketing and partnership arrangements with other web sites [3].

\section{E. Search Engine Optimization}

Search engine is a search engine in the form of a website to find information stored on other sites. Three basic tasks of search engines in their work:

a. Search the internet or select parts of the internet according to important words or keys.

b. Gives an index of the words searched for and where they found them.

c. Allows the user to search for words or word combinations found in the index [6]. 
Search Engine Optimization, commonly abbreviated as SEO, is a series of systematic processes aimed at increasing the volume and quality of traffic through search engines to the website or search engine algorithm. The goal of SEO is to place a website in the top position, or at least the first page of search results based on certain targeted keywords. Logically, a website that occupies the top position in the search results has a great chance of getting visitors [11]. Search Engine Optimization itself is divided into two, the first is Global SEO and the second is Local SEO. Global SEO includes SEO in general, while Local SEO includes local searches.

\section{F. Local Search Engine Optimization}

Every small company or multi location company can increase their business and attract more customers using the Local SEO strategy. Local SEO (Local Search Engine Optimization), which is often referred to as Local Search Engine Marketing is a very effective way to market a local business online, as it helps businesses promote their products and services to local customers right when they are looking for products and services. it's online [1].

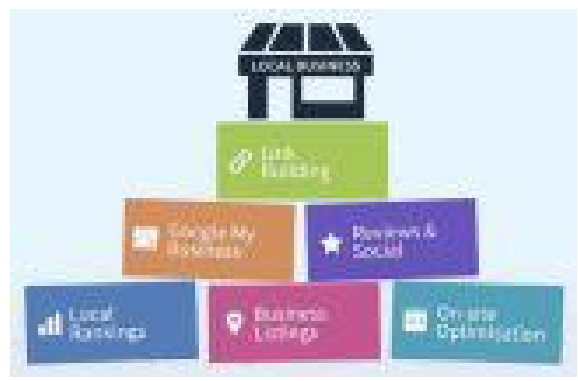

Figure 1. Local Business [1].

When a website utilizing Global SEO does not use Local SEO, the website will compete with websites of the same type with more numbers than if using Local SEO. Because as explained above, Local SEO targets local keywords, so the competition to appear on the top page is only in the location where the keyword is targeted. So, it is highly recommended if a location-based business takes advantage of Local SEO.

\section{G. Keyword}

It cannot be denied that the keyword has a major strength in the creation of SEO (Search Engine Optimization) and its success. A proper keyword determines a website to be at the top of the search engine search results index. (Search Engine), so it will be frequently visited by internet users. One or several keywords can be combined into a search sentence [9].

In searching for keywords that will be loaded, apart from direct observation to the user about how often a word is used to find what the user wants, of course, also requires tools supporting to determine what keywords to use. One of them is KWfinder. KWfinder itself is a tool for researching and analyzing keywords in an SEO. This tool can research keywords for the long term, showing what is currently popular, search volume and difficulty level results [7]. Besides KWFinder, there are also several tools that can be used to do keyword research, including the Adword Tool or Google Keyword Planner, Wordtracker, The Yahoo! Search Marketing Keyword Tool, and Semrush.

\section{H. Google My Business}

Google My Business or Google My Business is a service from google that makes it 
easier for businesses to be able to manage their existing business according to their location. The integration of maps in google my business will help business behavior in providing descriptions and connections to prospective customers [8].

Broadly speaking, the benefits of the Google My Business service are as a listing business. Especially for local customer-based businesses, or customers close to where the user's location / store is located. Simply put, when someone wants to search for something on Google Search Engine, Google will provide the search index results closest to the user's location. This means that it will point to a location not too far from the user's geographic coordinates. This place-oriented service is hereinafter known as Local Business Optimization [8].

The Google business site is a free professional site for a business that can be set up in no time. The creation is done automatically using information from existing, updated Business Profiles automatically when the business owner or manager creates changes to profile. Business owners or managers can choose from a variety of attractive and site themes that offer customers several ways to contact the owner or manager, such as via phone calls, SMS sending, or requests [4].

\section{Previous Research}

In doing the writing of this research, the writer certainly cannot be separated from the research references that have been there before. Among them are research by Deru R. Indika and Cindy Jovita [5] which discusses how social media that continues to develop can become a promotional media which in their research uses social media Instagram.

Then there is a research written by Joko Triyono M.Par., Damiasih, Syawal Sudiro [12] which discusses the effect of promotion on visitor satisfaction. There is also research from Noni Juliasari, Joseph Christian Sitompul [6] which discusses the role of search engines in finding information. After that, there is research from Dwi Budi Santoso [11] which discusses Search Engine Optimization. In addition, there is research from Amir Faruq Khairuzzaman [7] which discusses SEO and analysis keywords

\section{Analysis And Implementation}

\section{A. Promotion of the Sindaro Curug}

Since it was inaugurated on March 3, 2019, the Sindaro Curug Tour has carried out a promotion to introduce the Sindaro Waterfall Tour. The promotion that is currently running is to use social media such as Instagram, Facebook and WhatsApp. However, what is more intense is using Instagram, while using Facebook and WhatsApp only through the status of managers and local residents. The Instagram account of Curug Sindaro is also not well managed, because the Wisata Curug Sindaro account still uses a regular profile and does not use a business profile.

\section{B. Keyword Analysis}

A keyword is important in an SEO technique, both global SEO and Local SEO. These keywords can boost the traffic of the Sindaro Curug Tourism website that will be on Google My Business. The following is a keyword analysis that will be applied to the Sindaro Curug.

Tourism website using KWFinder with a location in Kebumen, Central Java, Indonesia:

Table III.1 Keyword Analysis 


\begin{tabular}{|c|c|c|c|}
\hline No. & Keyword & $\begin{array}{c}\text { Avg. } \\
\text { Monthly } \\
\text { Search }\end{array}$ & Overall KD \\
\hline 1 & Travel & 210 & 20 (Still Easy) \\
\hline 2 & $\begin{array}{c}\text { Holidays } \\
\text { Cheap }\end{array}$ & 10 & 22 (Still Easy) \\
\hline 3 & $\begin{array}{c}\text { Tourist } \\
\text { Attractions }\end{array}$ & 110 & 21 (Still Easy) \\
\hline 4 & $\begin{array}{c}\text { Tour } \\
\text { Packages }\end{array}$ & 10 & 31 (Possible) \\
\hline 5 & $\begin{array}{c}\text { Package } \\
\text { s } \\
\text { Vacation }\end{array}$ & 10 & 31 (Possible) \\
\hline
\end{tabular}

\begin{tabular}{|c|c|c|c|}
\hline 6 & $\begin{array}{c}\text { Travel } \\
\text { Cheap }\end{array}$ & 10 & 28 (Still Easy) \\
\hline 7 & $\begin{array}{c}\text { Nature } \\
\text { Tourism }\end{array}$ & 30 & 20 (Still Easy) \\
\hline 8 & Waterfall & 50 & 29 (Still Easy) \\
\hline 9 & Curug & 40 & 14 (Easy) \\
\hline 10 & $\begin{array}{c}\text { Tourism in } \\
\text { Kebumen }\end{array}$ & 480 & 17 (Still Easy) \\
\hline 11 & $\begin{array}{c}\text { Tourism } \\
\text { Kebumen }\end{array}$ & 1900 & 17 (Still Easy) \\
\hline 12 & $\begin{array}{c}\text { Tourist } \\
\text { attractions in } \\
\text { Kebumen }\end{array}$ & 590 & 17 (Still Easy) \\
\hline 13 & $\begin{array}{c}\text { Kebume } \\
\mathrm{n} \text { nature } \\
\text { tourism }\end{array}$ & 140 & 15 (Still Easy) \\
\hline
\end{tabular}

Average monthly searches, showing the average number of searches for this keyword and its similar variants based on the targeting setting and date range selected. This 
information is used to see how popular the keywords are over different times of the year.

Overall Keyword Difficulty (Overall KD), shows the difficulty of keywords based on market area with a minimum scale of 0 and a maximum of 100 . The lower the value, the easier it is to rank keywords in the first search result. The difficulty levels in the Overall Keyword Difficulty are effortless (0-9), go for it (10-19), easy (20-29), still easy (20-39), possible (40-54), hard (55-74)), very hard (75-84), don't do it (85-100).

The best average number of searches for the relevant keyword in the table above is "Kebumen Tourism". This is indicated by the average number of searches per month reaching 1,900 times and the difficulty level is still easy, which means that you can get a great chance to become the top search result on search engines. And for further implementation, the targeted keyword is "Kebumen Tourism".

C. Overview of the Google My Business Implementation

Process In an overview of the Google My Business implementation process, it is illustrated with an activity diagram that describes the overall implementation process.

Figure 2. Activity flow of the Google Implementation process

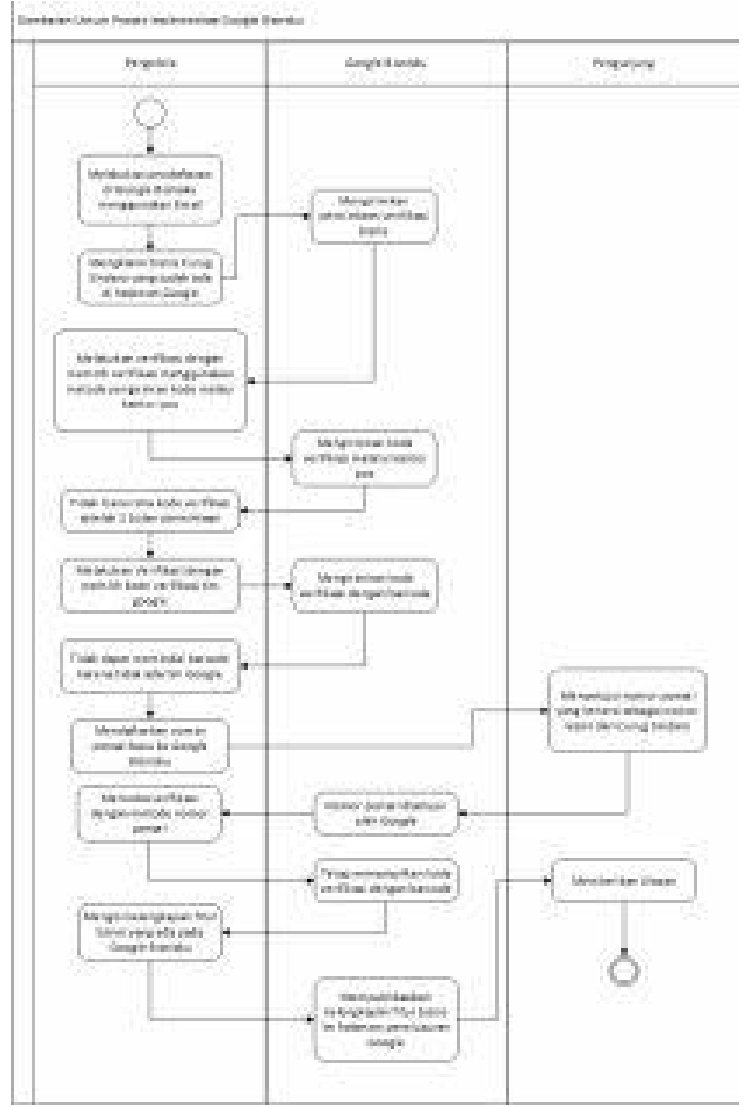

My Business In implementing Google My Business for the promotion of the Sindaro Curug Tour, the first step is to register an email with Google My Business. Because previously the manager had created a Google page but the manager did not remember the email and password, so registering on Google My Business uses a new account. And because previously Sindaro Curug Tour already has a Google page, all you need to do after registering is claiming the business. This business claim process requires 
a verification code. There are 3 options for this verification, via cellphone number, email and post office.

When waiting for the verification code to arrive, the manager can complete the features available in Google My Business. However, when the business has not been verified, there will be some features that cannot be opened because they have to wait for verification. However, managers can still fill in other features that can still be completed and Google My Business will publish it to the search page Google Search Engine.

D. Implementation Results

In this research, the resulting website for Curug Sindaro, search results on Google Search and Google Maps have used Local SEO. By using Google My Business as a medium for promotion, make your business well managed through existing features.

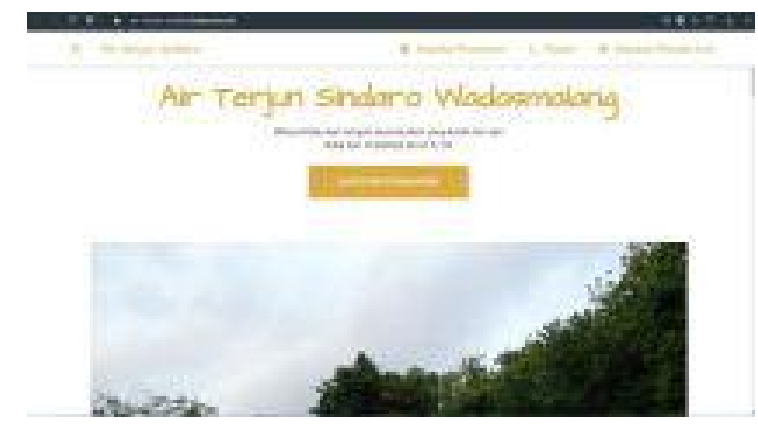

Figure 3. Website Curug Sindaro

\section{Closing}

\section{A. Conclusion The} conclusions in doing this research are:

a. Has promoted the Sindaro Curug Tour using an online marketing strategy by implementing Local Search Engine Optimization through Google My Business, namely by registering the business first, claiming the business on the page Google, trying available verification methods, then filling in the complete features available on Google My business, as well as publish the results of filling in the completeness of features so that they appear on search pages Google.

b. By analyzing 13 keywords with locations that have been arranged in Kebumen Regency, Central Java, there are 5 keywords used. However, when a search is carried out with targeted keywords, the website or the Sindaro Curug Tourism page has not appeared on the top page.

This research also helps the Mission of the RPJMD (Regional Medium Term Development Plan) Kebumen Regency 2016-2021 which is in line with the 2017 Kebumen District Development Priorities, which is in the tourism sector, namely the development of Tourism Marketing.

B. Suggestion 
Based on the stages that the author has done in this study, it is hoped that it can become the basis for further research considering that there are still many limitations faced. Therefore, the authors propose the development for further research, namely analyzing the keywords used for promotion accompanied by more complete theories regarding the use of keywords.

C. Recommendations

In carrying out this study the authors provide recommendations, namely complete the verification process to unlock features that cannot be activated. So that it can make it easier for managers to manage the website and interact with customers.

\section{References}

[1] BrightLocal, "What is Local SEO ?," BrightLocal Ltd, 2019. [Online]. [Accessed 20 September 2019].

[2] B. Kebumen, "Regulation of the Regent of Kebumen Number 24 of 2016 concerning the 2017 Local Government Work Plan,"Regency Government

Kebumen, Kebumen, 2016.

[3] D. Chaffey and FE Chadwick, Digital Marketing, Edinburg Gate: Pearson Education Limited, 2016.

[4] Google, "Google My Business," Google, [Online]. Available:

https://www.google.com/business/faq/?gmbsrc=w w-ww-et-gs-z-gmb-szh pro-zu. [Accessed 2010 2019].

[5] DR Indika and C. Jovita, "INSTAGRAM SOCIAL MEDIA AS A PROMOTIONAL MEANS TO INCREASE BUYING INTEREST CONSUMER," JOURNAL OF APPLIED BUSINESS, vol. 01, no. 01, p. 8, 2017.

[6] N. Juliasari and JC Sitompul, "Search Engine Application with Depth First Search Method," BIT, vol. 9, no. 1, p. 4, 2012.

[7] AF Khairuzzaman, "Implementation of Search Engine Optimization (SEO) on the Online Shop Website (Website Case Study: Warungkado.online)," Pasundan University, Bandung, 2018.

[8] R. Makmur, E- Management Commerce, Bandung: INFORMATIKA Publisher, 2018.

[9] IPAE Pratama, E-Commerce, E-Business, and Mobile Commerce, Bandung: INFORMATIKA, 2015.

[10] A. Purnomo, "UTILIZING INSTAGRAMS AS A COMMUNICATION MEDIA," MUHAMMADIYAH UNIVERSITY SURAKARTA, Surakarta, 2018. 
[11] DB Santoso, "Utilizing Search Engine Optimazion Technology as a Media toDINAMIK Increase the Popularity of Wordpress Blogs," Journal of Information Technology, vol. XIV, no. 2, p. 6, 2009.

[12] J. Triyono, D. and S. Sudiro, "THE INFLUENCE OF ATTRACTION AND TOURISM PROMOTION ON KAMPOENG VISITORS 'SATISFACTION IN THE VILLAGE OF MELIKAN, KLATEN DISTRICT," Tourism, vol. 12, no. 1, p. 12, 2018.

[13] Febriyanto, E., Naufal, R. S., \& budiarty, frizca. (2019). Attitude Competency Assessment in the 2013 curriculum based on elementary school Prototyping methods. IAIC Transactions on Sustainable Digital Innovation (ITSDI), 1(1), 87-96. https://doi.org/10.34306/itsdi.v1i1.6

[14] Sunarya, P. A., Aini, Q., Bein, A. S., \& Nursaputri, P. (2019). The Implementation Of Viewboard Of The Head Of Department As A Media For Student Information Is Worth Doing Final Research. ITSDI Journal Edition Vol. 1 No. 1 October 2019, 18.

[15] Febriyanto, E., \& Naufal, R. S. (2019). Attitude Competency Assessment in the 2013 Curriculum Based On Elementary School Prototyping Methods. IAIC Transactions on Sustainable Digital Innovation, 1(1), 87-96.

[16] Yusup, M., Aini, Q., Apriani, D., \& Nursaputri, P. (2019, December). PEMANFAATAN TEKNOLOGI BLOCKCHAIN PADA PROGRAM SERTIFIKASI DOSEN. In SENSITIf: Seminar Nasional Sistem Informasi dan Teknologi Informasi (pp. 365-371)

[17] Rao, S. S., \& Siddaiah, P. (2020). Design of Eight-Phase Sequences using Modified Particle Swarm Optimization for Spread Spectrum and Radar Applications. APTIKOM Journal on Computer Science and Information Technologies, 6(1), 30-40.

https://doi.org/10.34306/csit.v6i1.368

[18] S, S., T, R., \& SP, S. (2020). An optimized Rubber Sheet Model for Normalization Phase of IRIS Recognition . APTIKOM Journal on Computer Science and Information Technologies, 6(1), 20-29. https://doi.org/10.34306/csit.v6i1.356 